\title{
SPACES, TIMES AND ROLES IN THE SOCIAL CONTROL OF EVERYDAY LIFE'
}

\author{
Óscar FERNÁNDEZ-ÁLVAREZ \\ University of León \\ León /Spain \\ oscar.fernandez@unileon.es
}

\begin{abstract}
Social dynamics since the late seventeenth century have incorporated a series of discursive systems that are the fruit of the process of constituting power and control over public morals and safeguarding traditional religious values. The Church, as a repressive agent and shaper of consciences, has exercised multiple forms of control and surveillance that have been justified within the regime of daily life so that control could be effective. It has additionally implemented a system of domination. The general objective here is to describe and analyse the daily conduct within the convent as a total institution. We do so via a reconstruction that is based on descriptions of daily life and the tensions between rules and lived experiences and between the given conditions, as well as the way in which these appropriated the aforementioned descriptions. We analyse the collected data from the perspectives of anthropology and sociology, focusing primarily on Erving Goffman's symbolic interactionism, as well as from aspects of Foucault's work in the form of his consideration of the body as a social and cultural product and of the repertoire of inquiries that he undertakes
\end{abstract}

1 This work is a contribution to the project entitled "Clergy and Society in the Northwest of the Iberian Peninsula between the Fifteenth and Twenty-First Centuries," Ref. HAR2017-82473-P, funded by MINECO. 
on social practices of regulation and domination of bodies that have led to a significant imbalance in perceptions of control over our bodies and our sexuality. Our findings show that obedience is a basic requirement in the construction of and domination over the other, since it is inscribed in a discourse of power.

\section{Keywords}

Anthropology; institution; social control; symbolic interaction

\section{INTRODUCTION: THE FOUNDATION OF ORDER AND CONTROL, AND THE BASES FOR STUDYING THEM. (THEORETICAL AND METHODOLOGICAL APPROACH)}

Systems of control and surveillance take on multiple forms and varieties, and they are always justified within the order that underpins everyday life. They exist within different institutions that allow actions to be controlled and encourage, in addition to control of social life itself, the important need for a system of domination to be implemented.

The interest in and need to implement a social order in accordance with the needs of a given institution, situation or time make monitoring and control a daily practice.

The focus of this article is the practice of social control within total institutions that centre on religious practice and life, namely convents. Social dynamics since the early modern period - specifically, since the late seventeenth century - have incorporated a series of discursive systems that are the fruit of the process of constituting power and control to conserve public morals and safeguard traditional Christian values. Accordingly, a series of regulations - such rules in Spain's colonial era have, incidentally, been studied a great deal (Toquica 2001; Aranguren 2007)-was implemented but did not become successfully consolidated since, between the formulation of the rules and everyday practice, a wide gap existed. 
As Colmenares (1990) states, there was nothing more characteristic than nighttime rounds that sought to penetrate the privacy of hallways and alcoves to prevent social and moral disorder. The sources that we have consulted and the necessarily brief nature of a scholarly work have led this study to focus on convents of nuns. Accordingly, our general objective here is to describe and analyse the daily conduct within this institution. We do so via a reconstruction that is based on descriptions of daily life and the tensions between rules and lived experiences and between the given conditions, as well as the way in which these appropriated the aforementioned descriptions.

In terms of sources, we worked with biographies of religious figures, especially nuns. These were of the "confessional dialogue" kind that was quite abundant, and they focus on, for example, the nuns in Clarist convents, mainly in the early modern era. This is a type of document whose content was written up and - at times, it would seem-fabricated for pedagogical purposes within the convent. As we know, these documents served as "confessors' manuals."

These autobiographical narratives, as a space of expressiveness and female selfanalysis, had a particular impact, because, as Ferrus (2008) indicates, these spaces of confinement became the privileged space for female writing. Therefore, while marriage confined women to their tasks of wives and mothers and distanced them from the learned world, convents offered women the possibility of writing about themselves and giving themselves meaning as women. Accordingly, writing by women and convent writing became synonymous during the early modern era. Therefore, these institutions, considered genuine "republics of women," would allow them to be able to undertake a great number of tasks that they were kept away from in the world outside the convent walls (Martín 2000), including intellectual and writing roles. The most frequently practised genres within the cloisters were letters, narratives of nuns' lives and short poems. Life stories, biographies and chronicles were the genres in which the nuns spoke the most about themselves and their way of thinking, as well as about their bodies. These were the texts that confessors demanded most frequently and that were most frequently produced within convent tradition. In addition, while men spoke of "the" mystical experience, 
women spoke of "their" mystical experience, a stance that, moreover, made them privileged interlocutors of the divine.

To analyse the data collected, we have adopted the perspective of the Chicago School's anthropological and sociological tradition. We will focus primarily on the symbolic interactionism of Erving Goffman (1998, 2005, 2006). Mauro Wolf $(1979,21)$ describes Goffman's paradigm as an attempt to describe in detail the rules that control interactions in everyday life. He calls this the "Goffmanian attempt," indicating that it is a unique phenomenon in sociology. This School has focused primarily on what have been termed "total institutions" such as that which we consider here, hence our considering this approach to be a suitable element for this analysis.

Goffman's sociology, which is also sometimes called "microsociology" and often comprises highly detailed descriptions of things that might seem obvious, has faced two specific accusations: first, that is pays excessive attention to aspects that could be considered as irrelevant to the interactions, with there being a consequent lack of interest in the reality of the structures that form the basis of society; second, that it has a lack of historicity, derived from its phenomenological description of social situations. The crux of what makes its analysis relevant is still the structure of the interaction as the fundamental unit of social life. But without a doubt, its best contributions refer to the ways in which the experience of everyday life is organized. Using this paradigm, we will analyse aspects of the way in which social control and spiritual life unfolded inside the convent, especially for women.

Another point of analytical support comes from Foucault $(1985,1999)$, in the form of his consideration of the body as a social and cultural product and of the repertoire of inquiries that he undertakes on social practices of regulation and domination of bodies that have led to a significant imbalance in perceptions of control over our bodies and our sexuality. In addition, Foucault makes a critical contribution-one that is of great interest to and makes a major contribution to our analysis - to the development of discourse on social institutions.

The aspects that we will discuss in this work relate specifically to the interpretation and understanding of the feminine subject herself as well as of religious and social systems that govern the convent life of women and are 
supported by the vows of obedience, poverty and chastity. Likewise, we will observe monastic life according to the analytical criteria for total institutions, as well as to the spatial and temporal aspects of monastic life and other nun-related elements.

\section{DAILY LIFE IN THE INSTITUTION}

Based on the perspective described in the previous section, we will focus on the practice of female religious life within the cloisters as an institution and how it refers to the ways in which nuns appropriated the conditions in which they lived, to their experiences and to the ways in which they interpreted norms (Lüdtke 1995).

Our starting point is structured according to three aspects: first, and as the central issue, the multifunctionality inscribed within the post-Tridentine ecclesiastical current, observed from a historical perspective (Caro Baroja 1995); second, the cloisters as a space conducive to creativity, education, writing and the development of female intelligence and mysticism (Robledo 1994) and, therefore, as a space of freedom in a patriarchal world; and, finally, as a centralizing element for "truth" by means of a rigid framework of norms expressed in the way of perfection, mystical marriage, even in access to saintliness.

There is nothing better for achieving these ends than establishments as "total institutions" (Goffman 1998), understood as a single place of residence and work, where people live in physical and social isolation from what we might consider normal society or the rest of society. Convents are clearly separated from the rest of civil society by walls that defend against any social or disruptive interference in religious life. But far from living in an isolated manner, here people are part of their own society. The people kept in here share, in their confinement, a formally administered routine with a series of regulations and rules governing all of their lives' ambits, hours and activities. This is the context in which they devote themselves to their religious practices, which are nonetheless inferior to the desire to serve God. This makes institutions of this 
type extremely persuasive realities that are likewise effective in achieving their aims and decisive when it comes to setting their activities, with an organization of the given time as well as of the work to be done, the new "family" life, which facilitates, as well as the process of disculturation that comes with being subject to instructions of this type.

\section{THE CONDITIONS OF THE FORM OF EVERYDAY LIFE: THE INSTITUTIONALIZATION OF CONTROL (DISCUSSION AND RESULTS)}

The way of perfection within an institution such as the convent is structured around the divine office, which marks the organization of time and is guided by religious vows. As Lavrin (1993) states, poverty offers all the world's goods, chastity offers the pleasures of the body, and obedience offers freedom, which is the most noble and precious thing that man has. We will now examine this in detail.

The vow of poverty is the foundation of evangelical perfection and the main characteristic of Franciscan charism (Iriarte 199). However, the way of life of Clarist monasteries, like that in many Hispanic American monasteries described by Campo (1977), Benassy-Berling (1983), Muriel (1992) and Soeiro (1985), did not coincide with poverty's original intention. The initial will had changed due to the entry into the convent of property owned by the nuns, in addition to bequests and rents. The descriptions also show us possessions and donations from parents, etc. Therefore, poverty must be considered at an individual or private level rather than at a community one. As Toquica (2001) indicates in the case of the Santa Clara convent in Bogotá, the annual monetary revenues bequeathed by parents could be used by the whole community or left in the hands of the Prelate, and the community's money covered the nuns' clothing, medicines and sustenance. For daily expenses, the rules allowed them to have money and spend it on small daily items, and also on "personal treats, beautiful habits and interesting furniture"; all these things were condemned by the 
confessor and punished with excommunication and consequent deprivation of ecclesiastical burial.

With regard to the vow of chastity, Rubial (1995) states that this vow was an offer of the pleasures of the body. The idea that nuns should act as dead in life makes them renounce sexual pleasures. This was helped along by fasting and flagellation as instruments for resisting the temptation of the body. The descriptions warn that virginity had to be eternal and not tarnished or tempted by action or thought. So, for example, the confession diaries used by Toquica (2001) recommend that, if one does not want this treasure to wither or be stolen, all the senses must be closed, preserving modesty, honesty, moderation and sobriety in everything seen, heard, said, eaten, drunk and played.

An important element that can be pointed out with the help of Foucault (1985) is that the Church imposed a crackdown on sex. Foucault locates this mainly in the seventeenth century. From this moment on, mentioning sex became increasingly difficult and costly, as if to master it, it would be necessary, first of all, to reduce it in language, to control free circulation of it in discourse, expel it from what was said and extinguish words that are too forceful in making it present." Apparently, these prohibitions refer to the fear of mentioning it. They prevent its presence by avoiding any reference to it by name. Subsequently, modern modesty ensured it would not be mentioned thanks to the set of prohibitions that individuals issued to each other: "mutisms that impose silence by making people keep quiet" (Foucault 1999).

Aranguren (2007) points out that in the framework of such monitoring and of an ecclesial need for authority over sexuality and life in general, control over female life was a fundamental point in achieving its purposes. This control would respond to a European tradition that puts women in a place where constraints and ways of regulating their bodies are indispensable for the prevention of sins. Whether through education, the family, husbands, the home or the convent, women would be the object of constant vigilance by the Church. But despite sex being a topic that was to be avoided and that was constantly censored, it was a recurring, ever-present theme. And sex-related aspects are the most frequently mentioned ones in the descriptions, which produces the assumption that sex is one of the most troubling issues for the Church. 
Thus, regarding the regulation of the vow of chastity and sex-related matters within the convent, it is possible to unravel two elements. On the one hand, there is control of the senses to preserve the purity of body, mind and soul. Moreover, the body is not only cloistered, but also mortified. Nuns sought the pain of self-torture, but also of the disease complained of. Pain as "sacredness of punishment" or "savage sacredness" (Le Breton 1999) that seizes the person away from himself and makes him confront his limits, a capricious and arbitrary form that loves with unprecedented cruelty, became the most powerful language of the bodily technology that lives construct. Thus, there was revealed a horror of one's own body: "Each finger of the hands tormented me fiercely, the clothes that I wore, the air and the light that I gazed at... all day and all night brought a trembling and a dread that you could not put into words" (Aranguren 2007). Furthermore, after the suffering there is enjoyment, and manipulation of suffering becomes a way of overcoming the body's confines.

Then there is the essential theme of the mystical marriage with Christ. The descriptions indicate that any opening to the outside or flight with the mundane may be harmful to chastity. An example is looks from outsiders, "as the nuns' imaginations would be fed with dark phantoms and unchaste images. And in reciting the Divine Office, in prayer and in other community exercises, they shall live with their souls, which must be like clean crystal that the Divine Husband can be seen in, thrashing around in regret before the images of what they saw." According to Foucault (1988), things are very different with respect to censorship: "There is a real explosion of discourse around and on the subject of sex," but with a very rigorous cleansing of the authorized and used vocabulary. So much so that it is possible that a whole rhetoric of allusion and metaphor was codified, which manifests itself in new rules of decency that filter words, cleanse statements and also control enumerations. When and where, in which situations, between which interlocutors and in which kinds of social relations it was permissible to talk about sex were therefore defined. Through this, regions of absolute silence, or also, at least, of great tact and discretion, such as relations between parents and children, between educators and students, or between masters and servants were established (Foucault 1985). This was more so when it came to the religious education of a cloistered nun, which was imparted via 
ecclesiastical power. In the discourse the phenomenon is almost the reverse: there is an endless proliferation of sex as a theme. According to Foucault, this discursive fermentation accelerated during the eighteenth century, mainly in the field of the exercise of power itself: institutional incitement to talk about sex in detail. This is demonstrated, as Toquica (2001) points out, by the evolution of the Catholic pastoral and the sacrament of penance after the Council of Trent. Little by little, the nakedness of the questions asked in the medieval manuals and in most of those from the seventeenth century was concealed. Going into details was avoided. Discretion is recommended with increasing emphasis. But the extension of confession and confession of the flesh continued to grow under the impetus of the Counter-Reformation. The descriptions go to extremes regarding the care that should be taken over the sexual provocation incited by men's dark arts, and they also warn that other arts such as painting, poetry, literature, images of saints and even theological texts could undermine chastity.

It seems that, under these warnings, nuns would not have been able to learn anything other than that related to the divine office. This clearly would have hindered the construction of knowledge and cultivation of arts and letters, as happened within many female cloisters.

Touching directly associated with sexual sensitivity and linked to carnal pleasure was also strictly regulated. Warnings from confessors offer a glimpse of the way in which some nuns greeted men in the locutory, putting in the mouth of the Holy Spirit a patristic belief that considered woman to be impure by nature: a man who touches a woman cannot fail to be tainted. And this was much more so for virgins, because, even if the touch came from a hand alone, this was enough to alter the senses and make them acquiesce in delight, because what happens to the two sexes when they touch is the same as what happens to straw placed in a flame.

Foucault's approach is corroborated by Lavrin (1993) when he says that during the seventeenth century the ecclesiastical interest in controlling sexual impulses increased. In confessionals of the time, more questions were asked about specifics, and both research into and descriptions of all the possibilities of sinning sensually were increasingly precise. But it was necessary to do more than control contact between the two sexes. There was also a need to take care 
over contacts between sisters themselves. This is why confessor dialogues and descriptions contain warnings about special friendships among the nuns, tender friendships that often caused embarrassment to the community and careless friendships that would discredit the entire community and sacrifice all the bonds of the Divine Spouse. It was therefore proposed that they live in evangelical friendship, loving one another voluntarily, but fleeing the unique friendship.

Furthermore, as Loreto (1995) points out, the idea was to prevent everyday touching of bodies, as stipulated by the rules. Nuns and the abbess were obligated to sleep in bedrooms where the beds were "different and separated from one another" and two individuals sleeping "in the same bed" was banned. The nuns could not sleep accompanied by "one another, or not wearing their habits, or separately." Personal sensitivity was visually and physically limited through the use of special clothing, and control of the nuns' affections came to extend to maids and the laity. Even control over what was said and heard was so important that records of it - mainly what was discussed in the locutorywere kept, and the abbess was then told about what had been overheard.

All this control of the senses, as Toquica (2001) says, had a final objective for the sisters, namely marriage to Christ, for which the vow of chastity was a basic requirement. The female body was regarded as the property of the husband. The metaphor of the mystic wedding vows that inspired a clearly feminine form of religiosity dates back to the thirteenth century, and in the seventeenth century it was interpreted as a physical reality with patriarchal connotations: Christ was a jealous husband and wives were to remain faithful to him. Breaking this promise, which among lay people is called adultery, is called sacrilege among nuns (Rubial, 1995: 356). The personal relationship of the sister with her husband was a key element of religious discourse that the biographers used to reinforce the patriarchal model in gender relations. In this context, in the descriptions and dialogues, Jesus Christ was shown as a jealous husband and the sisters as wives foolish and unfaithful virgins. All this has a correlation with the possibilities for sensual sin, which were increasingly precise.

In short, the topic of chastity, as Aranguren (2007) says, is part of a broad conception of the body which extends to a notion of suffering that is 
understandable along with the notion of enjoyment. Mystical experiences, therefore, would be approachable from these notions, in order to establish what they say about subjective practices and an exemplifying an ordering discourse that surrounds and frames women in this context. Thus, suffering would be an essential point in the process of incorporation of social standards and a marker of the possibility of dialogue with God. Along this path, the body has a privileged place, since it will always be inscribed, stamped and mortified by the marks of such regulations.

Finally, the vow of obedience, as Toquica (2001) states, offers freedom as the most noble and precious element of the human being. Failure to comply with this vow that was fundamental for ecclesiastical control meant eternal damnation and sacrilege. In this whole process of assignment of freedom, a professed nun was subjected to two authorities: the abbess and the confessor. There was a certain rivalry between them, but, in the end, the confessor as spiritual director was the figure who really guided the nuns, decided whether or not the sisters were progressing in their spiritual life and measured the orthodoxy of their faith, since this was the figure who could denounce them to the authorities. Abbesses had to use penalties to oblige nuns to go to pray in unison and to eat as a community, and they could ban profane diversions. They had to ensure that at the grilles and receptions "time was not wasted all the while on useless and sometimes malicious conversation." In addition, according to the same description, they had to maintain a desirable and necessary silence. In the descriptions and dialogues, there is an adaptation of the rules to the specific circumstances of the local community. We observe, by means of what was prohibited, some of the everyday habits of the Clarisses that the Church sought to correct. The end rhetorically draws the stormy imaginary landscape of the consequences of disobedience and sin, built from the misogynist discourse of ecclesiastical power, but it also reveals some of the behaviour traits of some nuns (Lavrin 1993).

Life in the convent transcends a number of key issues regarding social and spiritual control and the economic and social order, with a necessary cloistering not only of the body but also of the soul. Community life, marked by the rule of the hierarchy and the convent roles, reproduces the social division that existed 
on the outside. The hierarchies set tasks, and through the vows the whole community was given commitments and obligations. In addition, reinforcement through convent education impelled women, from the earliest stage, to be humble and obedient, guarded at all times by watchers, listeners or portresses, who were responsible for symbolic control over the enclosed space.

In short, life in the convent community is marked by a whole series of differentiated and compartmentalized spaces according to: the activity being performed within these; the times, characterized by the day-to-day management of time according to canonical hours, and the commitment not to waste it, because time is the only thing that cannot be recovered if it is lost; and other elements that make it possible to categorize the convent as total institutions (Goffman, 2001; 2007), where ignoring the rules, even in one's thoughts, involves not only penance but voluntary mortification. All of this was brought together by a guiding thread: prayer, which articulates practices, repels suffering and supports community life in the convent.

\section{CONCLUSIONS}

In this study, we have focused on social control and regular life in the convent through the profession of vows of obedience, poverty and chastity. We have shown that obedience is a basic requirement in constructing others. Poverty was always understood within a scope that was more individual than communal. Chastity received the most attention, perhaps owing to the sexual disorder of the ecclesiastical hierarchy and its being the target of criticism from Lutherans (Caro Baroja 1995). All this configures the possibility of spiritual purity to enter into marriage with Christ. In addition, it gave the Church economic power through the inheritances or bequests it received.

Moreover, cloistering became an element for removing the possibility of women exerting influence over social and political issues. For nuns, their mystical experience would serve as a space for expression and public action within political, economic and social history. Paradoxically, it could be said that the nature of internal detachment particular to mysticism, and the loss of 
boundaries between subject and object, favoured women. Representing themselves in the image and likeness of the suffering Christ offering his body as a sacrifice would apparently open the space in which women began to constitute traits of their search for autonomy. However, it is possible to also suggest that this self-awareness, which would open up an internal detachment (offer of the body), would chain feminine joy more than ever to the masculine order.

Ferrus (2005) said that convent life is linked to confession and works based on secrecy. Writing from obedience entails inscribing oneself in a discourse of power and demonstrating hidden aspects. But this gesture becomes ambivalent, because from here it is possible to unleash a strategy that puts before the eyes of the authority a discursive gesture that otherwise would be understood as subversive. Women manage to protagonize access to a space for self-expression that would otherwise be completely denied to them.

Likewise, the constitution of "feminine intimacy" is rightly framed by the presence, more active than ever, of God. The pleasure of the feminine would be inscribed with this in regulated privacy, in personal and modern experience of self-control of the passions. If this process of subjectivation ends up favouring the inscribing of subjects in an even more captivating social order, it is because it does not operate in a negative way only. As Foucault (1992) said, if power was nothing more than repressive, if it did nothing other than say no, do we really think that it would be obeyed? What gives power its hold and makes it accepted is simply that it does not bear down only as a force that says no but is actually cross cutting, producing things, inducing pleasure, creating knowledge and producing discourses.

\section{REFERENCES}

- Aranguren, Juan Pablo. 2006. "Buscando goces ilícitos". En Repensando a Policéfalo. Diálogos con la memoria histórica a través de documentos de archivo. Siglos XVI al XIX. Eds. Marta Herrera, Camila Aschner y Taina Lizarazu. Bogotá: Editorial Pontificia Universidad Javeriana. 
- Aranguren Romero, Juan Pablo. 2007. “¿Cómo se inscribe el sufrimiento en el cuerpo? Cuerpo, mística y sufrimiento en la Nueva Granada a partir de las historias de vida de Jerónima Nava y Saavedra y Gertrudis de Santa Inés". Fronteras de la Historia 12: 17-52.

- Benassy-Berling, Marie-Cecile. 1983. Humanismo y religión en Sor Juana Inés de la Cruz. México: Universidad Nacional Autónoma de México.

- Campo Lacasa, Cristina. 1977. Historia de la iglesia en Puerto Rico. San Juan: Instituto de Cultura Puertorriqueño.

- Caro Baroja, Julio. 1995. Las formas complejas de la vida religiosa, siglos XVI y XVII. Barcelona: Galaxia Gutenberg-Círculo de Lectores.

- Colmenares, Germán. 1999. “La ley y el orden social: fundamento profano y fundamento divino". Boletín Cultural y Bibliográfico 22: 3-20.

- Ferrús Antón, Beatriz. 2005. "Heredar la Palabra: Vida, escritura y cuerpo en América Latina". Trabajo de grado de doctorado. Universidad de Valencia.

- Ferrús Antón, Beatriz. 2008. "Mayor Gloria de Dios es que lo sea una Mujer... Sor María de Jesús de Ágreda y Sor Francisca Josefa de la Concepción del Castillo (Sobre la Escritura Conventual en los Siglos XVI y XVII)". Revista de Literatura vol. LXX, 139 (enero-junio): 31-46.

- $\quad$ Foucault, M. 1999. Las palabras y las cosas. Madrid: Siglo XXI.

- Foucault, Michel. 1985. Historia de la sexualidad. 1. La voluntad de saber. México: Siglo XXI Editores.

- Foucault, Michel. 1992. Microfísica del poder. Madrid: La Piqueta.

- Goffman, Erving. 1979. Relaciones en público. Microestudios de Orden Público. Madrid: Alianza Universidad.

- Goffman, Erving. 1987. La presentación de la persona en la vida cotidiana. Buenos Aires: Amorrotu editores.

- Goffman, Erving. 1998. Internados. Ensayos sobre la situación social de los enfermos mentales. Buenos Aires: Amorrortu editores.

- Goffman, Erving. 2005. Frame analisys. Los marcos de la experiencia. Madrid: CIS- Siglo XXI.

- Goffman, Erving. 2006. Estigma. La identidad deteriorada. Buenos Aires: Amorrortu editores. 
- Iriarte, Lázaro. 1994. Letra y espíritu de la Regla de santa Clara. Asís. Valencia $\mathrm{OMF}$.

- Lavrin, Asunción. 1993. "La vida femenina como experiencia religiosa: biografía y hagiografía en Hispanoamérica colonial". Colonial Latin American Review 2: 1-2.

- Le Breton. 1999. Antropología del dolor. Barcelona: Seix Barral.

- Loreto López, Rosalba. 1995. “La sensibilidad y el cuerpo en el imaginario de las monjas poblanas del siglo XVII". En Memoria del II Congreso internacional El monacato femenino en el imperio español, monasterios, beaterios, recogimientos y colegios. México: Centro de Estudios de Historia de México.

- Lüdtke, Alf. 1995. "De los héroes de la resistencia a los coautores: 'Alltagsgeschichte' en Alemania". En La historia de la vida cotidiana, editado por Luis Castells. Ayer, $\mathrm{n}^{\circ} 19$. Madrid: Marcial Pons Librero.

- Martín, Luis. 2000. Las hijas de los conquistadores. Barcelona: Casiopea.

- Moncó, B. 2000. Antropología e Historia: un diálogo interdisciplinar. Revista de Antropología Social 9: 159-176.

- Muriel, Josefina. 1992. Las mujeres de Hispanoamérica: época colonial. Madrid: Mapfre

- Rubial García, Antonio. 1995. "Un caso raro: la vida y desgracias de sor Antonia de San Joseph, monja profesa en Jesús María". En Memoria del II Congreso internacional El monacato femenino en el imperio español, monasterios, beaterios, recogimientos y colegios. México: Centro de Estudios de Historia de México.

- Soeiro, Susan. 1985. “Las órdenes femeninas en Bahía, Brasil, durante la Colonia: implicaciones económicas, sociales y demográficas". En Las mujeres latinoamericanas: perspectivas históricas, 1677-1800, compilado por Asunción Lavrin. México: Fondo de Cultura Económica.

- Toquica Clavijo, M. 2001. Religiosidad femenina y la vida cotidiana del Convento de Santa Clara de Santafé, Siglos XVII Y XVIII. Una mirada detrás del velo de Johanna de San Esteban. Revista Colombiana de Antropología, 37: 152-186.

- Wolf, Mario. 1988. Sociologías de la vida cotidiana. Madrid: Cátedra. 